\title{
KIOBEL AND THE LAW OF NATIONS
}

\author{
By Zachary D. Clopton*
}

Since 1789, the Alien Tort Statute (ATS) has provided federal court jurisdiction for tort suits by aliens for violations of the law of nations. ${ }^{1}$ Though debate certainly exists about the method by which ATS-appropriate torts are identified, ${ }^{2}$ the Supreme Court has acknowledged that the substantive content of ATS causes of action is derived from the law of nations. ${ }^{3}$ In Kiobel v. Royal Dutch Petroleum Co., the Supreme Court justices addressed not the substance of ATS cases but the reach of that statute. ${ }^{4}$

At least at the time of the Judiciary Act of 1789 , the law of nations included not only substantive international law but also international jurisdictional law. ${ }^{5}$ Like the substantive law of nations that provides ATS causes of action, international jurisdictional law is an important part of the international legal order. And yet, in a decision about the reach of law-of-nations tort law-and in the search for post-Kiobel alternatives— too little attention has been paid to the jurisdictional branch of the law of nations. This essay briefly summarizes an approach to lawof-nations torts that tracks international jurisdictional law, which is broader than current ATS doctrine in some respects and narrower in others.

\section{Prescriptive Jurisdiction}

One aspect of international jurisdictional law potentially relevant to law-of-nations cases is the international law of prescriptive jurisdiction. Prescriptive jurisdiction describes the international-law limits of the reach of a state's laws. ${ }^{6}$ As others have argued, the limits of prescriptive jurisdiction are not technically the right framework for the ATS. The ATS is a

* Public Law Fellow, University of Chicago Law School.

${ }^{1} 28$ U.S.C. $\$ 1350$ ("The district courts shall have original jurisdiction of any civil action by an alien for a tort only, committed in violation of the law of nations or a treaty of the United States.").

${ }^{2}$ The Supreme Court has required that "any claim based on the present-day law of nations to rest on a norm of international character accepted by the civilized world and defined with a specificity comparable to the features of the 18th-century paradigms we have recognized." Sosa v. Alvarez-Machain, 542 U.S. 692, 725 (2004).

${ }^{3}$ Kiobel v. Royal Dutch Petroleum Co., 133 S.Ct. 1659, 1663 (2013); Sosa, 542 U.S. at 732. In Kiobel, for example, the plaintiffs brought international law claims for crimes against humanity, torture and cruel treatment, and arbitrary arrest and detention. 133 S.Ct. at 1663.

${ }^{4}$ Kiobel, 133 S.Ct. 1659.

5 See, e.g., Stewart Jay, The Status of the Law of Nations in Early American Law, 42 VAND. L. REV. 819, 821-22 (1989). For a summary of U.S. interpretation of international jurisdictional law, see 1 RESTATEMENT (THIRD) OF THE FOREIGN RELATIONS LAW OF THE UNITED STATES \$\$401-88 (1987) [hereinafter RESTATEMENT].

${ }^{6}$ Prescriptive (or legislative) jurisdiction is defined as the authority of a state "to make its law applicable to the activities, relations, or status of persons, or the interests of persons in things, whether by legislation, by executive act or order, by administrative rule or regulation, or by determination of a court." RESTATEMENT, supra note 5 , $\$ 401(\mathrm{a})$. 
jurisdictional statute, not a conduct-regulating one, and ATS causes of action are derived from international law, not domestic law. ${ }^{7}$ Yet it is not wholly unreasonable to think about prescriptive jurisdictional limits on law-of-nations causes of action, ${ }^{8}$ and the Court treated Kiobel as a prescriptive jurisdictional case.

International jurisdictional law provides an internationally accepted set of bases for prescriptive jurisdiction. The Restatement (Third) of the Foreign Relations Law of the United States identifies five: (1) territoriality, (2) nationality, (3) objective territoriality, (4) passive personality, and (5) universal jurisdiction. ${ }^{9}$ The opinions in Kiobel, however, called for narrower limits on the prescriptive reach of law-of-nations torts than international jurisdictional law allows. Chief Justice John Roberts drew his limits from a territorial principle, that is, the presumption against extraterritoriality. ${ }^{10}$ While Justice Stephen Breyer referred to "international jurisdictional norms," ${ }^{11}$ his opinion concurring in the judgment defined limits in light of "American interests" rather than international law. ${ }^{12}$ In concert with the international division of labor delineated in international jurisdictional law, future courts and legislatures addressing law-of-nations torts should broaden the prescriptive reach of these causes of action to the limits of international prescriptive jurisdiction.

\section{Adjudicatory Jurisdiction}

According to the Supreme Court in Sosa v. Alvarez-Machain, ATS cases must involve international-law causes of action that are specific and universal. ${ }^{13}$ Concern that ATS cases reach too far, therefore, arises not from the content of the rules but from the forum for adjudicating them — when should a U.S. court hear a law-of-nations tort case? International juris-

${ }^{7}$ E.g., William S. Dodge, Alien Tort Litigation and the Prescriptive Jurisdiction Fallacy, 51 HARV. INT'L L.J. ONLINE 35,37-44 (2010), at http://www.harvardilj.org/articles/dodge.pdf (arguing that the courts are not subject to prescriptive jurisdictional rules because they are applying (not prescribing) substantive law); Anthony Colangelo, Kiobel Insta-Symposium: Kiobel Contradicts Morrison, OPINIO JURIS, May 10, 2013, at http://opiniojuris.org/ 2013/05/10/kiobel-insta-symposium-kiobel-contradicts-morrison (arguing that the presumption against extraterritoriality, a prescriptive jurisdictional rule, should not apply to ATS cases because no U.S. conduct-regulating rule exists).

${ }^{8}$ E.g., Michael D. Ramsey, International Law Limits on Investor Liability in Human Rights Litigation, 50 HARV. INT'L L.J. 271 (2009). One could treat the ATS as impliedly creating causes of action within the limits established by international jurisdictional law or as authorizing federal courts to define common-law causes of action within the limits established by international law. See Cannon v. Univ. of Chi., 441 U.S. 677 (1979) (implied causes of action); Textile Workers Union v. Lincoln Mills, 353 U.S. 448 (1957) (implied federal common lawmaking power). Those international law limits could be read into the term law of nations in the ATS or applied via the Charming Betsy canon. See Murray v. Schooner Charming Betsy, 6 U.S. (2 Cranch) 64, 118 (1804) ("[A]n act of Congress ought never to be construed to violate the law of nations if any other possible construction remains ....").

${ }^{9}$ RESTATEMENT, supra note 5, $\$ 402$.

${ }^{10}$ Kiobel v. Royal Dutch Petroleum Co., 133 S.Ct. 1659, 1664-69 (2013) (applying the presumption against extraterritoriality).

${ }^{11}$ Id. at 1673 (Breyer, J., concurring).

${ }^{12} \mathrm{Id}$. at 1674 ("I would interpret the statute as providing jurisdiction only where distinct American interests are at issue."); see also Julian Ku \& John Yoo, The Supreme Court Unanimously Rejects Universal Jurisdiction, FORBES.COM, Apr. 21, 2013, at http://www.forbes.com/sites/realspin/2013/04/21/the-supremecourt-unanimously-rejects-universal-jurisdiction (observing that every justice in Kiobel rejected universal jurisdiction).

${ }^{13}$ Sosa v. Alvarez-Machain, 542 U.S. 692, 725 (2004). 
dictional law addresses this question under the heading "adjudicatory jurisdiction." ${ }^{14}$ As such, adjudicatory jurisdiction is the natural locus for limits on the reach of a domestic court applying internationally accepted substantive rules.

Applying the international law of adjudicatory jurisdiction to law-of-nations tort cases would narrow current ATS doctrine because international adjudicatory jurisdiction is narrower than personal jurisdiction in U.S. constitutional law. International adjudicatory jurisdiction does not countenance tag jurisdiction ${ }^{15}$ and seems less amenable to general jurisdiction than U.S. law, even after Goodyear Dunlop Tires Operations v. Brown. ${ }^{16}$ The international law of adjudicatory jurisdiction, therefore, could provide meaningful limits on ATS cases, yet the Kiobel Court ignored this body of law in its search for limits on the federal courts as fora for law-of-nations torts. ${ }^{17}$ Human rights advocates filing amicus briefs in Kiobel suggested that the ATS was sufficiently cabined by existing rules from personal jurisdiction to forum non conveniens to international comity, but they, too, did not look to the international law of adjudicatory jurisdiction. ${ }^{18}$ Should the Court reconsider the reach of the ATS, or should future courts or legislatures (in the United States or abroad) address law-of-nations cases, the law of adjudicatory jurisdiction may help set appropriate boundaries for the domestic-court enforcement of universally accepted norms of international law. ${ }^{19}$

\section{Conclusion}

In deciding Kiobel, the Supreme Court expressed caution with respect to the international discord that could result from ATS cases that reach beyond the scope of the United States' authority. ${ }^{20}$ The justices had access to- - but declined to adopt - internationally agreed guidelines on exactly that issue. The international law of adjudicatory and prescriptive jurisdiction is a part of the law of nations that the ATS incorporated into U.S. law, and it should be part of law-of-nations tort law as well. If the Court had applied such limits in Kiobel, it would have

\footnotetext{
${ }^{14}$ Adjudicatory (or judicial) jurisdiction is defined as the authority of a state "to subject persons or things to the process of its courts or administrative tribunals, whether in civil or in criminal proceedings, whether or not the state is a party to the proceedings.” RESTATEMENT, supra note 5, \$401(b); see id. \$\$421-23.

${ }^{15}$ Compare id. $\$ 421$, cmt. e (noting that “" $\left.\mathrm{t}\right]$ ag' jurisdiction, i.e., jurisdiction based on service of process on a person only transitorily in the territory of the state, is not generally acceptable under international law"), with Burnham v. Superior Court, 495 U.S. 604, 628 (1990) (finding personal jurisdiction on this basis).

${ }^{16}$ Compare RESTATEMENT, supra note 5, \$421 (describing international law of prescriptive jurisdiction), with Goodyear Dunlop Tires Operations, SA v. Brown, 131 S.Ct. 2846 (2011) (limiting, but not eliminating, general jurisdiction in U.S. law).

${ }^{17}$ Perhaps the Supreme Court could have limited ATS cases by infusing law-of-nations causes of action with lawof-nations limits on adjudicatory jurisdiction, see supra note 8, or by applying some notion of "international due process" to law-of-nations claims, Soc'y of Lloyd's v. Ashenden, 233 F.3d 473, 479-81 (7th Cir. 2000) (discussing "international due process" in a judgment recognition case).

${ }^{18}$ E.g., Supplemental Brief of Professors of Civil Procedure and Federal Courts as Amici Curiae on Reargument in Support of Petitioners, Kiobel v. Royal Dutch Petroleum Co., 133 S.Ct. 1659 (2013) (No. 10-1491); Supplemental Brief of Yale Law School Center for Global Legal Challenges as Amicus Curiae in Support of Petitioners, Kiobel v. Royal Dutch Petroleum Co., 133 S.Ct. 1659 (2013) (No. 10-1491). The Kiobel briefs are available online at http://cja.org/section.php?id=509. Perhaps this decision will prove wise-if the Court also adds adjudicatoryjurisdiction requirements to the class of ATS cases that survived Kiobel_-because the remaining ATS regime would be narrower in both prescriptive and adjudicatory reach.

${ }^{19}$ For a case in which the Supreme Court could entertain limits on adjudicatory jurisdiction, see Bauman v. DaimlerChrysler Corp., 644 F.3d 909 (9th Cir. 2011), cert. granted, 133 S.Ct. 1995 (U.S. Apr. 22, 2013 ) (No. 11-965).

${ }^{20}$ Kiobel v. Royal Dutch Petroleum Co., 133 S.Ct. 1659, 1664-65 (2013).
} 
placed meaningful limits on ATS cases (which it seemed wont to do) and avoided causing international discord (its stated goal), all the while staying true to the words of the ATS and contributing to the rational ordering of the international legal system. In the same way, whether it is through common law, domestic statutes, or international agreements, future regimes of domestic civil enforcement of public international law should not ignore the international jurisdictional rules that have been an important part of the law of nations. In the words of Rosalyn Higgins, former president of the International Court of Justice, "There is no more important way to avoid conflict than by providing clear norms as to which state can exercise authority over whom, and in what circumstances." 21 